\title{
Review of Installation Status and Major Environmental Issues of Floating Photovoltaic Power Plants (FPVs)
}

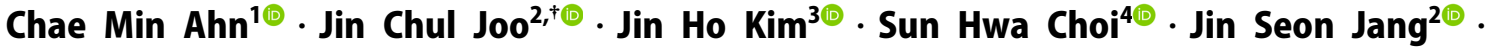 \\ Hyeon Woo Go ${ }^{2 \odot}$
}

'Department of Environmental Engineering, Hanbat National University

${ }^{2}$ Department of Civil \& Environmental Engineering, Hanbat National University

${ }^{3}$ Land \& Housing Institute

${ }^{4}$ Korea Association for Aquatic Ecosystem Restoration

(Received February 24, 2021; Revised March 17, 2021; Accepted March 22, 2021)

Objectives: After investigation of types, characteristics, and domestic and overseas installation cases of floating photovoltaic power plants (FPVs), both power generation capacity and coverage ratio of the FPVs were analyzed, and the major environmental issues impacting on water quality and aquatic ecosystem were reviewed.

Methods: Both information and data of the FPVs extracted from existing literature and provided by the FPVs installation companies were statistically analyzed.

Results and Discussion: FPVs divided into three types such as pontoon type, frame type, and solar tracking type are installed in various ways by country and region. As of the second half of 2018, the global power generation capacity of FPVs is $1.3 \mathrm{GWp}$, and FPVs have been intensively installed in China, Japan, Korea, Taiwan, and UK. While the pontoon type has been mainly installed in other countries except Korea, the frame type was mainly installed in Korea. Among various water resources, FPVs installed in agricultural water resources have various power generation capacity and coverage ratio whereas FPVs installed in industrial, rainwater storage, and other water resources have relatively high power generation capacity and coverage ratio. Compared to FPVs installed in other water resources, FPVs installed in drinking water resources have relatively low power generation capacity and coverage ratio. After reviewing the major environmental issues related to FPVs (i.e., leaching of hazardous substances, deterioration of water quality and aquatic ecosystem, changes in water temperature and illumination, and disturbance of aquatic ecosystem), the impacts of the FPVs on water environment are found to be insignificant, and the positive effects (i.e., mitigation of green tide and restoration of the aquatic ecosystem) are confirmed.

Conclusions: Although the impacts of the FPVs on water environment (water quality and aquatic ecosystem) are found to be insignificant, additional experiments reflecting extreme conditions and long-term continuous monitoring of water quality and aquatic ecosystem in terms of coverage ratio, array and type of FPVs are required.

Keywords: Floating Photovoltaic Power Plants, Power Generation Capacity, Coverage Ratio, Water Quality and Aquatic Ecosystem, Environmental Issues

The Korean text of this paper can be translated into multiple languages on the website of http://jksee.or.kr through Google Translator. 


\title{
수상태양광 발전시설 현황 및 주요 환경 쟁점 고찰
}

\author{
안채민 $^{1 \oplus} \cdot$ 주진철 ${ }^{2+\oplus} \cdot$ 김진호 $^{3 \oplus} \cdot$ 최선화 $^{4 \oplus} \cdot$ 장진선 $^{2 \oplus} \cdot$ 고현우 $^{2 \oplus}$
}

\author{
${ }^{1}$ 한밭대학교 환경공학과 \\ 2한밭대학교 건설환경공학과 \\ 3 한국토지주택연구원 \\ 4한국수생태복원협회
}

목적: 수상태양광 발전시설의 유형과 특징, 국내외 설치사례를 조사·분석하여, 수상태양광 발전시설의 발전용량과 수면 점유율을 비교하고, 수질 및 수생태계에 미치는 영향에 관련된 주요 환경 쟁점에 대해 고찰하였다.

방법: 국내외 수상태양광 발전시설에 대한 기존 문헌 및 수상태양광 설치 회사에서 제공하는 정보와 데이터를 추 출하여 통계적으로 분석하였다.

결과 및 토의 : 수상태양광 발전시설은 일반적으로 폰튠형, 프레임형, 태양 추적형의 3 가지 유형으로 구분되어 국가 별·지역별로 다양하게 설치되고 있다. 2018년 하반기 기준 전 세계적으로 수상태양광 발전용량은 $1.3 \mathrm{GWp}$ 로 중 국, 일본, 한국, 대만, 영국 순서로 수상태양광 발전시설이 많이 설치되고 있으며, 한국을 제외한 다른 국가들에서 는 폰튠형이 한국의 경우 프레임형이 주로 설치되었다. 수원의 활용구분에 따라 식수용 수자원은 낮은 발전용량과 수면점유율로 설치된 반면, 농업용 수자원은 다양한 발전용량과 수면 점유율로 설치되었다. 이외에도 산업용, 빗물 저장, 기타 수자원에는 비교적 높은 발전용량과 수면 점유율로 설치되어 있음을 확인하였다. 수상태양광 발전시설 설치에 따른 주요 환경 쟁점인 기자재 유해물질 용출, 정체구역 발생에 따른 수질변화, 수면 점유율에 따른 수질변 화 및 수생생물 군집변화, 수온·조도 변화, 전자파로 인한 수생태계 교란 가능성에 관련된 기존 문헌 고찰결과, 수 상태양광 발전시설이 미치는 영향은 미미하며, 녹조저감과 수생태계 복원의 긍정적인 효과를 확인할 수 있었다.

결론: 수상태양광 발전시설의 설치가 수환경(수질·수생태계)에 미치는 영향은 미미한 것으로 확인되었으나, 극한 조건을 반영한 추가 실험, 수상태양광 수면 점유율, 배열 및 유형별 장기간 지속적인 수질·수생태계 모니터링이 필 요한 것으로 판단된다.

주제어 : 수상태양광 발전시설, 발전용량, 수면 점유율, 수질·수생태계, 환경 쟁점

\section{1. 서론}

산업화 이후 지속가능하지 않은 화석연료의 과도한 사용으 로 기후변화 촉진, 미세먼지 발생과 원자력발전소의 유지관리 위험성으로 인해 다양한 신·재생에너지의 개발과 응용이 더욱 활발히 진행되고 있다. ${ }^{1-3)}$ 재생에너지 3020('17.12)에 따르면 2030년까지 신·재생에너지 발전량 목표비중을 전체 에너지 발전량의 $20 \%$ 인 $63.8 \mathrm{GW}$ 로 설정하였으며,5), 이중 신규설비 용량의 $95 \%$ 이상을 태양광·풍력 등 청정에너지를 중심으로 공급할 것으로 계획하였다. ${ }^{4)}$ 다양한 신·재생에너지 중 친환경 적이며 산업/고용 유발 효과가 높은 태양광 발전은 최근 전 세계적으로 급성장하였으나 기존 육상태양광 발전시설은 건물, 임야, 산림 등 육상에서의 설치로 산림훼손, 토사유출,
지형 및 경관훼손 등 다양한 환경 문제와 재난 위험성이 야기 되고 있는 실정이다. ${ }^{1,6-8)}$ 이러한 육상태양광 발전시설의 대안 으로 호소, 하천 등 수면 위에 설치하는 수상태양광(floating photovoltaic power plants, FPVs)이 제시되고 있다. ${ }^{1-3,5-8)}$

수상태양광은 2007년 미국 포도농장에서 최초로 설치된 이 후 유럽, 중국, 일본, 한국 등에서 주로 적용되고 있으며 ${ }^{1,9)}$, 주로 수면활용도가 낮은 댐, 저수지, 하구 담수호 및 농업용 생산기반 시설로서의 방조제 내측 유휴수면을 활용하여 설 치되고 있다. ${ }^{1,6,9)}$ 수상태양광은 수면위에 설치되어 냉각효 과·난반사 등을 통해 육상태양광 발전 대비 약 $11 \%$ 이상 발전효율이 우수한 것으로 보고되며 ${ }^{6,7,10)}$, 수면 차광을 통한 어류의 서식환경 제공 및 녹조 확산을 저감하는 장점이 보고 되고 있다. ${ }^{6,7,10)}$ 
수상태양광 발전시설은 국제적으로 2015년 이후 급격하게 증가하고 있으며, 2018년 12월 기준 전 세계 수상태양광 발전 시설의 설치용량은 약 $1.3 \mathrm{GWp}$ 로 보고되었으며, 이러한 발전 용량은 2000년도 전 세계 육상태양광 발전시설 전력 생산량 에 해당한다. ${ }^{11-13)}$ 전 세계에는 $400,000 \mathrm{~km}^{2}$ 이상의 인공 저수 지(artificial reservoir)가 조성되어 ${ }^{11,14)}$, 이용 가능한 수면적을 기준으로 수상태양광 발전시설을 설치할 경우 이론적 발전 잠재량은 TW 규모의 전력 생산 가능성이 있는 것으로 보고되 었다. ${ }^{11,12)}$ 이러한 수상태양광 발전시설은 농업용 저수지가 발 달된 아시아 국가를 중심으로 최근에 설치가 빠르게 증가하고 있다. ${ }^{11,12)}$

하지만 수상태양광 발전시설은 수면 위에 설치되므로 수질 오염 및 수생태계 교란의 우려와 중금속 용출, 구조적 안전성, 경관훼손 등 관련된 다양한 환경 쟁점이 사회적으로 제기되고 있다. ${ }^{1,5,11,15-19)}$ 그러나 수상태양광 설치로 인해 수환경(수질수생태계)에 미치는 영향에 관련된 연구는 기존 육상태양광 발전시설 연구결과 대비 초기단계로 장기간 지속적 모니터링 을 통해 수질 및 수생태계에 미치는 영향, 환경 위해성 등 종 합적인 연구가 필요한 실정이다. $1,5,11,15-19)$ 따라서 본 연구에서 는 수상태양광 발전시설 설치국가, 형태, 발전용량, 수원, 수 면 점유율 등이 제시된 광범위한 문헌 및 온라인 조사를 통해 전 세계 수상태양광 발전시설의 유형과 특징, 수원 및 수면 점유율 등을 요약-정리하여 시사점을 도출하였으며, 국내외 설치사례와 환경 관련 주요 쟁점이 제시된 선행연구결과 등을 종합 검토하여 기술하고자 한다. 본 연구의 주요 목적은 (1) 수상태양광 발전시설의 국내외 설치사례 분석, (2) 수상태양 광 발전시설의 발전용량 비교 분석, (3) 수상태양광 발전시설 설치의 국내외 수면 점유면적 비교, (4) 수상태양광 발전시설 의 국내외 주요 환경 쟁점에 대한 선행연구 검토 및 고찰로 구성되어 있다.

\section{2. 국내외 수상태양광 발전시설 설치사례 분석}

\section{1. 수상태양광 발전시설 유형 및 특징}

수상태양광 발전시설은 육상태양광 발전시설과 동일하게 태 양광 모듈(photovoltaic module), 모듈 지지체(module frame), 배전설비(electric power system)로 구성되어 있으나, 수면 위 에 설치되기 때문에 부력을 발생시키는 부력체(buoyant body) 와 구조물을 고정할 수 있는 계류장치(anchoring), 무게추 (weight) 등이 추가적으로 설치된다. ${ }^{6,12,13,20)}$ 특히 다습지역에 서는 내습 및 방수 특성의 태양광 모듈이 요구되며, 환경 유해 물질이 용출되지 않는 재질이 활용되고 있으며 ${ }^{1,8-10,21,22)}$, 풍속 으로 인한 불안정한 수면 위에서 구조적 안전성을 유지하기 위한 기술이 지속적으로 개발되고 있다. ${ }^{6,10)}$

수상태양광 발전시설은 다양한 형태로 설치되지만 일반적 으로 (1) 태양광 모듈 지지체와 부력체가 일체화된 폰튠형 (pontoon type), (2) 태양광 모듈 지지체와 부력체가 분리된 프레임형(frame type), (3) 태양광 모듈이 태양을 추적하여 상 하 또는 동서로 회전하는 태양 추적형(solar tracking type) 등 3 가지 유형으로 구분하여 Table1에 제시하였다. 폰튠형은 경 사각을 $20^{\circ}$ 이하로 낮춰 풍하중을 줄이는 구조로 시공비용을 절감할 수 있으나, 프레임형 대비 상대적으로 발전효율이 낮 으며 취송류 흐름을 저해하여 수류순환을 일부 방해하는 단점 이 있다.,12,20) 프레임형은 경사각을 $33^{\circ}$ 내외로 유지하여 구조 적 안전성과 발전효율이 높으며 원활한 수류순환이 이뤼지나, 시공비용이 높아 댐과 같은 넓은 수면적에 대규모로 설치되고 있다. ${ }^{1,12,20)}$ 상하 추적형은 태양광 일주기 이동경로를 따라 상 하로 회전하는 시스템으로 태양각에 따라 설치면적이 다소 많이 소요되며 시공 및 유지관리 비용이 상대적으로 높아 현 재 단축 추적식형만 설치되고 있다. 마지막으로 동서 추적형 은 태양광 일주기 이동경로를 따라 동서로 회전하는 시스템으 로 고정식(stationary)과 동일한 설치면적으로 높은 발전효율 을 보이며(20-30\%), 일괄회전(rotary)으로 회전방식이 단순한 장점이 있으나, 태양광과 수심변화에 따른 상하 이동을 고려 해 추가적 설치비용이 필요한 단점이 있다. ${ }^{6,9,16,23,24)}$

\section{2. 국내외 수상태양광 발전시설 설치사례 분석}

2018년 하반기를 기준으로 국내 수상태양광 발전시설을 설 치·운영하는 기관은 한국수자원공사, 한국농어촌공사, 한국 수력원자력, 한국동서발전이 있다. 한국수자원공사는 합천댐 (0.5 MWp, 2012), 보령댐(2 MWp, 2016), 충주댐(3 MWp, 2017) 총 3 개 다목적댐에 수상태양광 발전시설의 설치 및 운 영을 통해 $5.5 \mathrm{MWp}$ 규모를 운영 중이다. ${ }^{925)}$ 농업용 저수지에 설치되어 운영되는 수상태양광 발전시설은 총 33 개소(43.6 $\mathrm{MWp})$ 이며, 이중 한국농어촌공사에서 22개소( $25.8 \mathrm{MWp}$ )를 직접 운영하며, 민간에서 수면활용 임대사업을 통해 총 11 개 소(17.8 MWp)를 위탁 운영하고 있다. ${ }^{918,19)}$ 이외에도 한국수 력원자력, 한국동서발전이 각 1 개소의 수상태양광 발전시설 을 관리·감독하고 있다. ${ }^{9,26,27)}$

국외의 수상태양광 발전시설 설치 사례를 Table2에 제시하 였다. 미국의 경우, 농업용 저수지에 수상태양광 발전시설을 설치한 사례는 Kunde $(\mathrm{CA})$ 와 Orlando $(\mathrm{FL})$ 가 있으며, 각각의 수상태양광 발전용량은 $10 \mathrm{kWp}$ 와 $32 \mathrm{kWp}$ 로 두 발전시설 모 두 수면 점유면적이 만수면적의 $3 \%$ 를 차지하고 있다. ${ }^{28,29)}$ Dixon (CA)에는 산업용 연못에 $507 \mathrm{kWp}$ 규모의 발전용량 인 수상태양광을 설치하였으며, 수면 점유면적은 만수면적 의 $15 \%$ 를 차지하고 있다. ${ }^{28,29)}$ 이외에도 수처리 시설의 수면 에 수상태양광 발전시설을 설치한 사례는 Walden $(\mathrm{CO})$ 와 Sayreville (NJ)가 있으며, 각각의 수상태양광 발전용량은 74 $\mathrm{kWp}$ 와 $4.4 \mathrm{MWp}$ 이고, 수면 점유면적은 만수면적의 $52 \%$ 와 $21 \%$ 로 상대적으로 높은 수면 점유율(수면 점유율/만수면적, coverage ratio)을 나타내었다. ${ }^{28,29)}$ 
Table 1. Comparison of structures for floating photovoltaic power plants.

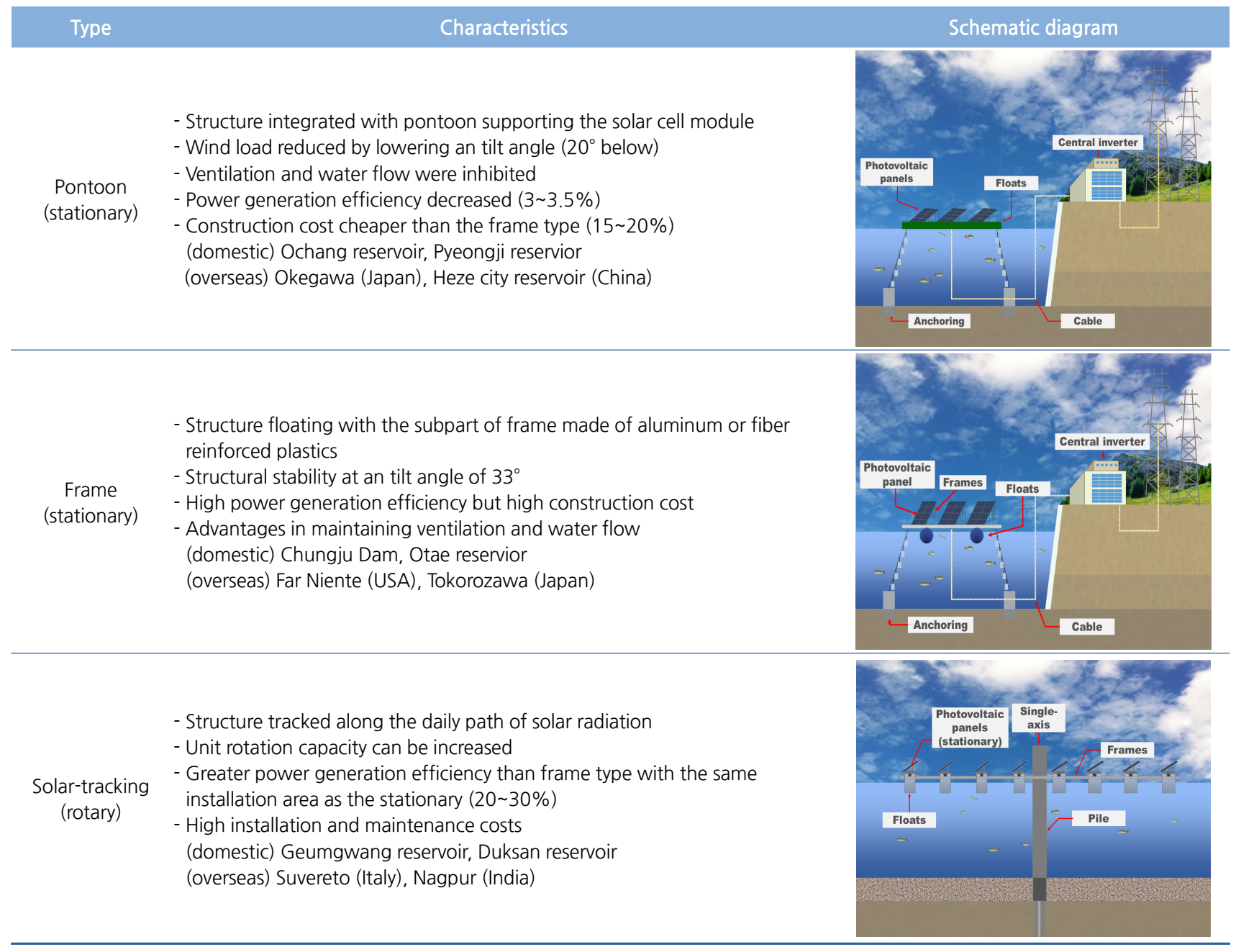

유럽의 경우, 영국에서 식수로 사용하고 있는 Queen Elizabeth II 저수지에는 $6.3 \mathrm{MWp}$ 의 수상태양광 발전시설을 설치하였 으며, 수면 점유면적은 만수면적의 5\%를 차지하고 있다. ${ }^{28-30)}$ 농업용 저수지에 설치된 사례는 이탈리아의 Pontecorvo와 네 덜란드의 Azalealaan가 있으며, 각각 발전용량은 $343 \mathrm{kWp}$ 와 $1.8 \mathrm{MWp}$ 이고, 수면 점유면적은 만수면적의 $43 \%$ 와 $47 \%$ 에 해당되었다. ${ }^{28,29}$ 벨기에의 Hesbay frost의 산업용 연못에는 $998 \mathrm{kWp}$ 발전용량인 수상태양광을 만수면적의 $35.5 \%$ 를 점유하게 설치하였다. ${ }^{28,29)}$ 독일에서는 채석장에서 채굴 작 업 후 형성된 인공 호수에 $749 \mathrm{kWp}$ 발전규모의 수상태양광을 설치하였으며, 수면 점유면적은 만수면적의 $2 \%$ 에 해당되 었다. ${ }^{28)}$

중국은 2015년 이후 수상태양광 발전사업이 활발해지면서 2019년 기준 전 세계 수상태양광 설치용량의 73\%(950 MWp) 를 차지하였다. ${ }^{11)}$ 농업용 저수지에 수상태양광 발전시설을 설 치한 사례는 Pei country (Jiangsu), Heze city (Shandong) 및 Yunxi (Yueyang)으로 발전용량은 각각 $1 \mathrm{MWp}, 600 \mathrm{kWp}$ 및 $20 \mathrm{MWp}$ 이며, 수면 점유면적은 저수지 만수면적의 $29 \%$,
$16 \%, 30 \%$ 에 해당된다. ${ }^{28,29,31)}$ Weshan (Jining)과 Anhui GCL (Huaibei)은 채석장에 형성된 인공호수로 각각 $31 \mathrm{MWp}$ 와 $32.7 \mathrm{MWp}$ 발전용량 규모의 수상태양광을 설치하였으며, 설 치면적은 만수면적의 $70 \%$ 와 $30 \%$ 에 해당되었다. ${ }^{28,29,31)}$

일본은 빗물저류지, 저수지, 연안 등 다양한 수면환경에 수 상태양광 발전시설을 설치·활용하고 있다. ${ }^{1,12)}$ 빗물저류지인 Hanamidai (Satiama)에는 1.2 MWp 규모의 수상태양광 발전 시설을 설치하였으며, 수면 점유면적은 만수면적의 $86 \%$ 로 높 은 수면적 점유율을 나타내고 있다. ${ }^{28)}$ 농업용 저수지에 수상 태양광 발전시설을 설치한 사례는 Isawa IKE (Tokushima), Shita와 Ue (Hyogo), Yokawach Kami (Hyogo)로 각각의 발전 용량은 $631 \mathrm{kWp}, 665$ 와 $594 \mathrm{kWp}, 621 \mathrm{kWp}$ 이며, 수면 점유면 적은 만수면적의 $57 \%, 61 \& 63 \%, 40 \%$ 를 차지하고 있다. ${ }^{28,29)}$ Yamakura dam (Chiba)에 설치된 수상태양광은 일본 최대 규 모로 $13.7 \mathrm{MWp}$ 의 발전용량을 가지며, 수면 점유면적은 저수 지 만수면적의 $32 \%$ 에 해당된다. ${ }^{28,32)}$

동남아시아의 경우, 말레이시아의 Ulu Sepri에 위치한 저 류지에는 $270 \mathrm{kWp}$ 규모의 수상태양광 발전시설이 설치되었 
Table 2. Installation status and characteristics of oversea floating photovoltaic power plants.

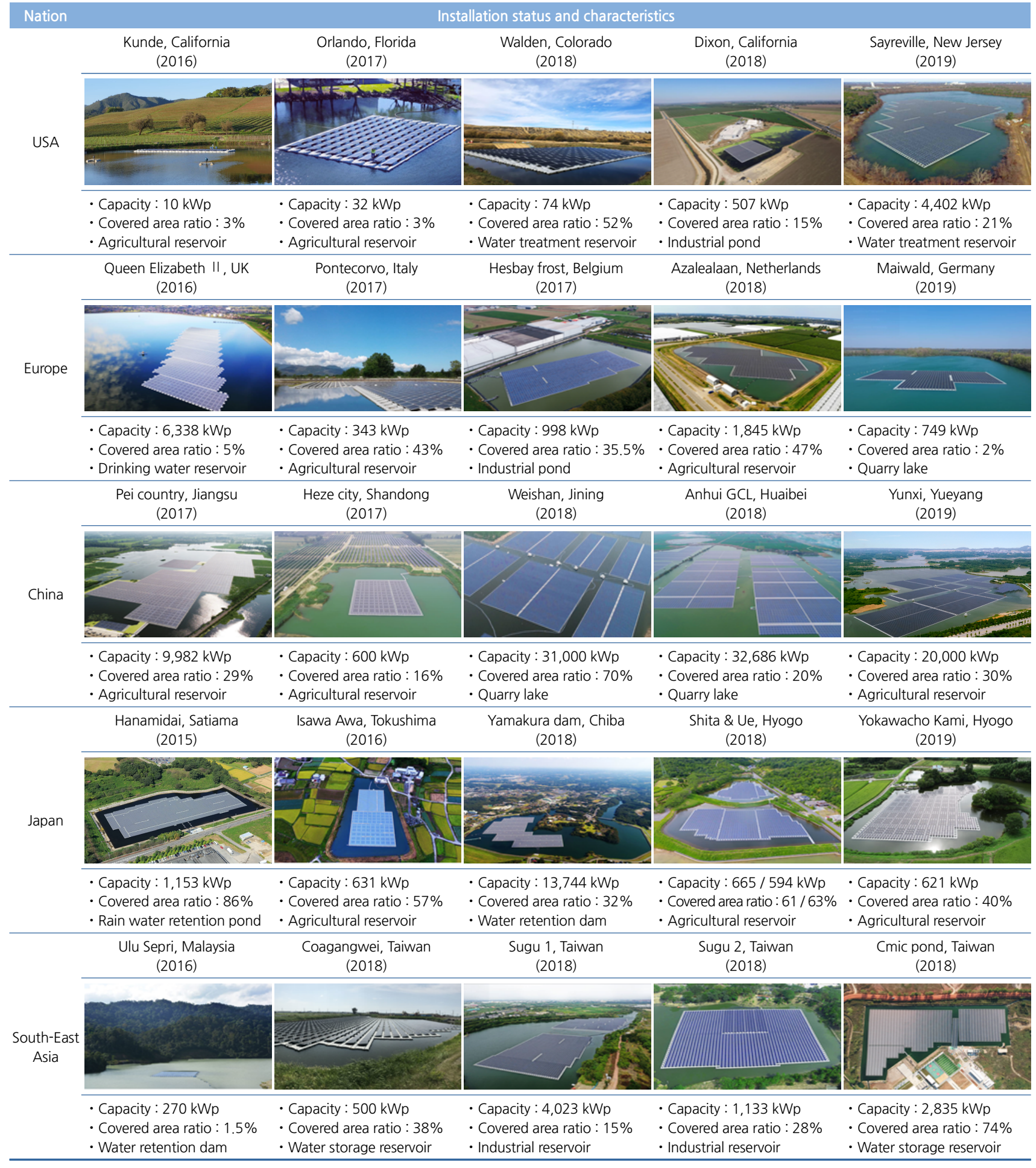

으며, 수면 점유면적은 만수면적의 $1.5 \%$ 에 해당된다. ${ }^{2830)}$ 대 만의 산업용 저수지인 Sugu 1, 2에 설치된 수상태양광은 각 각 $4 \mathrm{MWp}$ 와 $1.1 \mathrm{MWp}$ 의 발전규모로 수면 점유면적은 저 수지 만수면적의 $15 \%$ 와 $28 \%$ 에 해당된다. ${ }^{28,29)}$ 또한, 대만에 Coagangwei의 농업용 저수지에는 $500 \mathrm{kWp}$ 규모의 수상태양 광을 설치하였으며, 수면 점유면적은 저수지 만수면적의 $38 \%$
에 해당된다. ${ }^{28)}$ 캄보디아의 빗물저류지인 Cmic pond에 설치 된 수상태양광은 $2.8 \mathrm{MWp}$ 규모의 발전용량을 가지며, 수면 점유면적은 만수면적의 $74 \%$ 를 차지하고 있다. ${ }^{28,29)}$

\section{3. 국내외 수상태양광 발전시설 발전용량 비교}

수상태양광 발전시설은 2008년 미국의 캘리포니아 Far 


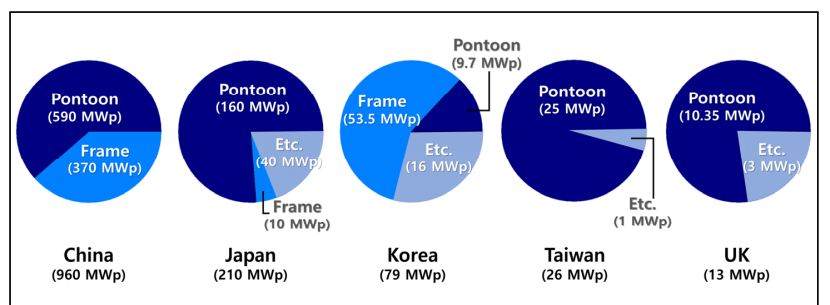

Fig. 1. Comparison of power generation capacity for floating photovoltaic power plants of top 5 countries.

Niente 농장 $(175 \mathrm{kWp})$ 에 최초 상업용 규모로 설치된 이후 2013년 상반기부터 일본과 한국에 MW 규모의 수상태양광 발전시설이 설치되었다. ${ }^{11,12)}$ 수상태양광 발전시설은 24 개국 이상의 국가에 설치되어 있으며, 대부분 수상태양광 발전시설 의 설치는 농업용 저수지가 발달된 국가인 중국, 일본, 한국 등 아시아에서 활발히 진행되고 있다. ${ }^{11,12,33)}$

2018년 12월 기준, 설치된 수상태양광 발전시설 총 발전용 량은 약 $1.3 \mathrm{GWp}$ 로 이 중 중국이 가장 많은 발전시설 용량을 차지하였으며, 일본, 한국, 대만, 영국 및 기타 국가로 구성되 어 있다. ${ }^{13)}$ 발전용량 상위 5 개국의 수상태양광 발전시설 유형 을 Fig. 1 에 비교 및 제시하였다. 중국은 전 세계 수상태양광 발전용량의 $73.8 \%$ (960 MWp)를 차지하며 ${ }^{13)}$, 수상태양광 설 치용량 측면에서 선두 국가로 Huainan (Anhui)에 $150 \mathrm{MWp}$ 규모의 세계 최대 수상태양광 발전시설을 보유하고 있다. ${ }^{13,31}$ 중국의 수상태양광 발전시설은 폰튠형이 $960 \mathrm{MWp}$ 중 590 $\mathrm{MWp}$ (61.5\%)를 차지하고 있으며, 프레임형은 $370 \mathrm{MWp}$ (38.5\%)로 폰튠형이 주로 설치되었다. ${ }^{13,28,31,34,35)}$

일본은 전 세계 수상태양광 발전용량의 $16.2 \%$ (210 MWp) 차지하며, 일본의 수상태양광 발전시설 유형은 폰튠형이 160 $\mathrm{MWp}$ (76.2\%)로 대부분을 차지하며 ${ }^{13)}$, 프레임형은 $10 \mathrm{MWp}$ (4.8\%)를, 폰튠형과 프레임형을 제외한 기타 유형이 $40 \mathrm{MWp}$ (19.0\%)로 구성되어 중국과 마찬가지로 폰튠형이 주로 설치 되어 있는 것으로 조사되었다. ${ }^{13,28,36-40)}$

한국은 전 세계 수상태양광 발전용량의 6.1\% (79 MWp)로 2012년 다목적댐인 합천댐에 수상태양광 발전시설이 설치 후 2014년 경기도 안성 금광저수지에 태양 추적형 수상태양광 발전시설 $(465 \mathrm{kWp})$ 을 최초로 설치한 국가이다 ${ }^{13,16)}$. 최근 새 만금 방조제에 $2.1 \mathrm{GWp}$ 규모의 수상태양광 발전시설 설치를 2단계로 구성하고 있으며, 1 차는 $1.2 \mathrm{GWp}$ 수상태양광 발전시 설을 2022년까지 완공하고 2차에는 나머지 $900 \mathrm{MWp}$ 규모의 수상태양광 발전시설을 2025년까지 설치할 예정이다. ${ }^{41)}$ 한국 의 수상태양광 발전시설 유형은 다른 국가와 다르게 프레임형 이 53.3 MWp (67.4\%)로 우세하며, 폰튠형이 9.7 MWp (12.3\%) 를, 프레임형과 폰튠형을 제외한 회전식 추적형이 $16 \mathrm{MWp}$ $(20.3 \%)$ 를 차지하였다. ${ }^{13,16,25,28,30,42-45)}$

대만은 전 세계 수상태양광 발전용량의 $2.0 \%$ (26 MWp)를 차지하며, 수상태양광 발전시장이 가장 빠르게 성장하는 국가

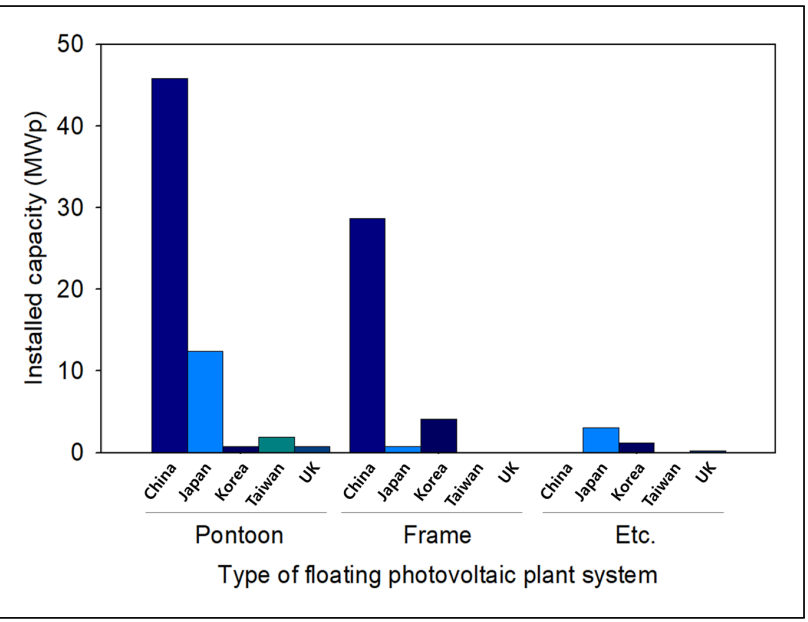

Fig. 2. Comparison of power generation capacity with type of floating photovoltaic power plants of top 5 countries.

중 하나이다. ${ }^{13)}$ 대만의 수상태양광 유형은 폰튠형이 $25 \mathrm{MWp}$ (96.2\%)로 대부분을 차지하며, 한국과 마찬가지로 회전축을 중심으로 태양을 추적하는 추적형(기타)이 $1 \mathrm{MWp}(3.8 \%)$ 를 나타낸다. ${ }^{13,28,31)}$

영국은 전 세계 수상태양광 발전용량의 $1.0 \%$ (13 MWp)를 차지하며, 다른 아시아 국가들과 유사하게 육상태양광 발전시 설 설치공간의 부족으로 국토확보를 위해 수상태양광 발전시 설을 설치하기 시작하였다. ${ }^{13)}$ 영국의 수상태양광 유형은 폰튠 형이 $10.35 \mathrm{MWp}$ (76.9\%)로 대부분을 차지하며, 폰튠형을 제 외한 기타 유형으로 $3 \mathrm{MWp}$ (23.1\%)를 설치하였다. ${ }^{13,28)}$

수상태양광 발전시설의 유형은 폰튠형, 프레임형 및 기타유 형으로 크게 3 가지로 구분하고 있으며 ${ }^{1,6,9,12,16,20,23,24)}$, 수상태 양광 발전용량 상위 5 개국의 수상태양광 발전시설 유형별 발 전용량을 Fig. 2에 제시하였다. 폰튠형의 경우 다른 발전시설 유형 대비 중국과 일본에서 높은 비율을 나타내었다. 특히 중 국은 Anhui에 위치한 채석장 호수에 수면 점유면적 60,000 $\mathrm{m}^{2}$ 에 $70 \mathrm{MWp}$ 규모의 수상태양광을 다양한 수상태양광 설치 업체인 Ciel \& Terre Co., D3Energy Co. 및 Techwin Co.에서 설치하며 가장 높은 발전용량을 나타내었다. ${ }^{28,29,30)}$ 프레임형 의 경우 폰튠형 다음으로 높은 발전용량으로 조사되었으나 중국을 제외한 다른 국가들은 발전용량 수치가 매우 낮게 조 사되었다. 그러나 한국은 다른 국가들과 달리 폰튠형보다 프 레임형이 높은 발전용량을 나타내었다. ${ }^{25,28,30,42-45)}$ 이러한 결 과는 바람과 파도의 피해 발생이 비교적 낮은 한국의 저수지 를 고려하여 바람과 파도에 대한 구조적 안정성이 취약하지만 발전효율이 비교적 우수한 프레임형을 선호한 결과로 판단된 다. ${ }^{646)}$ 폰튠형과 프레임형을 제외한 기타 유형의 수상태양광 발전시설은 전 세계적으로 매우 낮은 발전용량을 나타내며, 기타 유형은 대부분 회전식 수상태양광 발전시설로 구성된 다. ${ }^{25,28,30,42-45)}$ 


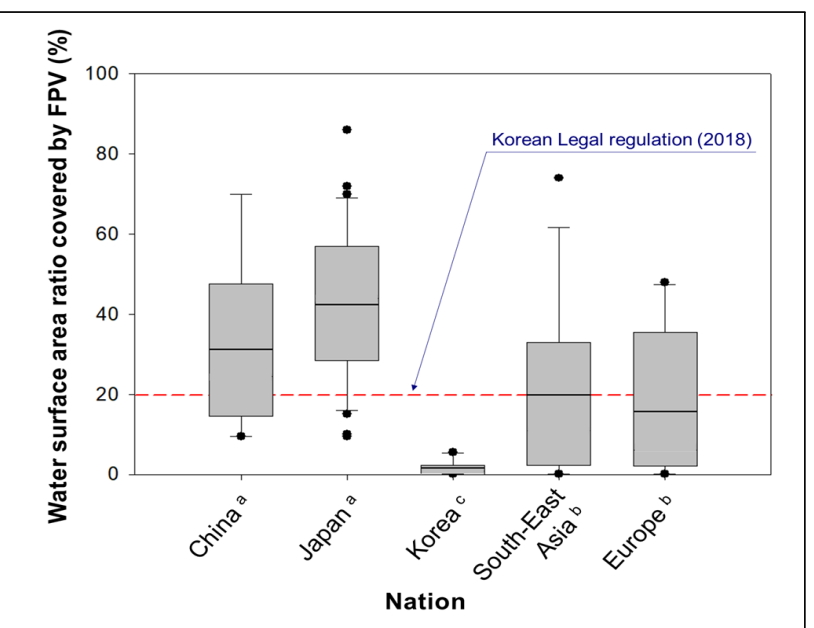

Fig. 3. Comparison of surface coverage ratio of floating photovoltaic power plants.

\section{3. 국내외 수상태양광 발전시설 수면 점유율 비교}

수상태양광 발전시설 설치에 따른 국가별 수상태양광 발전 시설 수면 점유율을 Fig.3에 비교 및 제시하였다. 일반적으로 수상태양광 발전시설의 수면 점유율은 국가별로 매우 다양하 게 조사되었으며, 일본과 중국이 비교적 매우 높은 수면 점유 율을 보인 반면, 동남아시아와 유럽 그리고 한국의 순서로 수 면 점유율이 감소하였다. ${ }^{13,25-40,42-45)}$ 국가별 수상태양광 수면 점유율의 차이를 비교하기 위해 IBM SPSS (ver. 22)의 일원분 산분석(one-way analysis of variance, one-way ANOVA)을 활 용하였다. 국가별 수상태양광 수면 점유율의 차이를 비교하기 위한 one-way ANOVA 분석결과, 중국 $(\mathrm{n}=10)$ 과 일본 $(\mathrm{n}=49)$ 이 수면 점유율이 가장 높은 그룹(a)으로 조사되었으며, 동남아 시아 $(\mathrm{n}=15)$ 와 유럽 $(\mathrm{n}=13)$ 의 수면 점유율이 중간그룹(b)으로 분류된 반면, 한국(n=11)의 수면 점유율은 가장 낮은 것(c)으 로 분석되었다 $(p<0.05)$. 이러한 결과는 수질과 수생태계에 미치는 장기적인 영향을 고려해 수면 점유율을 $20 \%$ 미만으 로 제안한 한국농어촌공사의 조례(2018)에 따른 결과로 판 단된다.

수상태양광 발전시설 설치에 따른 국가별 수자원과 수면 점 유율, 발전용량의 관계를 Fig.4에 제시하였다. 국가별로 다양 한 수자원과 수면 점유율, 발전용량을 비교한 결과, 수상태양 광 발전시설이 설치되어 있는 수자원의 주요 용도는 농업용, 식수, 산업용, 빗물저장용 및 기타로 구분되었다. ${ }^{13,25-40,42-45)}$ 대 부분의 수상태양광 발전시설은 다양한 수면 점유율로 농업용 수자원에 설치된 것으로 조사되었으며, 다른 국가 대비 일본 과 중국이 농업용 수자원에 수상태양광 발전시설을 가장 많이 설치하였고, 한국, 동남아시아, 유럽 순서로 감소하였다. 식수 수자원에는 주로 동남아시아, 한국과 유럽에서 비교적 낮은 수면 점유율 $(20 \%$ 미만)로 수상태양광 발전시설이 설치되었 으며, 동남아시아와 유럽, 일본에는 산업용 수자원(수력발전

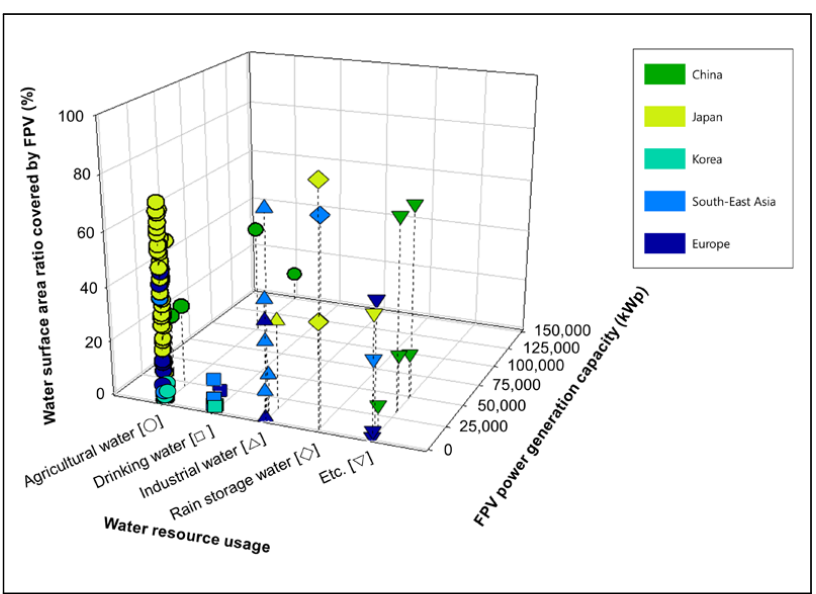

Fig. 4. 3-D Scatter chart among power generation capacity, water resource usage, and water surface coverage ratio of floating photovoltaic power plants.

댐, 산업폐수 처리 저수지 등)에 주로 수상태양광 발전시설이 설치된 것으로 나타났다. 빗물저장 수자원은 다른 수자원 대 비 높은 수면 점유율 $20 \%$ 이상)로 일본과 동남아시아에 주로 설치되었으며, 기타 수자원인 채석장 내 인공호수, 수처리 저 수지 및 습지 등 국가별로 다양한 수상태양광 발전시설 수면 점유율을 나타내었다.

수상태양광 발전시설이 설치된 국가별 수자원과 발전용량 의 관계를 검토한 결과, 중국의 경우 대부분 농업용 수자원과 기타 수자원(채석장 내 인공호수)에 수상태양광 발전시설이 설치되었으며 다른 국가들에 비해 매우 높은 발전용량을 나 타내었다. 일본은 주로 농업용 수자원과 빗물저장 수자원에 수상태양광 발전시설이 설치되었으며, 비교적 높은 수면 점 유율을 나타내었으나 중국 대비 낮은 발전용량으로 조사되었 다. 한국의 경우 농업용 수자원과 식수 수자원에 주로 설치되 었으며 다른 국가들에 비해 매우 낮은 수면 점유율 $(20 \%$ 미 만)로 조사되었다. 동남아시아는 다양한 수자원과 수면 점유 율로 수상태양광 발전시설이 설치되었으나 주로 농업용 수자 원에 설치되었으며, 대부분 낮은 발전용량을 나타내었다. 유 럽 또한 다양한 수자원에 수상태양광 발전시설이 설치되었으 나 일본과 동남아시아 대비 낮은 수면 점유율을 나타내었으 며, 중국을 제외한 다른 국가들과 유사한 발전용량으로 조사 되었다.

결론적으로 대부분의 수상태양광은 농업용 수자원에 설치 되어 있었으며, 다양한 발전용량과 수면 점유율을 나타내었 다. 또한, 산업용, 빗물저장, 기타 수자원은 다양한 수면 점유 율을 나타내었지만 비교적 높은 수면 점유율과 발전용량을 나타내었다. 반면에 식수 수자원은 다른 수자원 대비 매우 낮 은 수면 점유율과 발전용량을 나타낸 것으로 조사되었으며, 이는 수상태양광 발전시설 설치가 수질과 수생태계에 미치는 장기적인 영향과 잠재적 위해성을 고려한 것으로 판단된다. 


\section{4. 수상태양광 발전시설의 주요 환경 쟁점 고찰}

수상태양광 발전시설은 수면 위에 설치되므로 수환경과 관 련된 다양한 환경 쟁점이 제기되고 있으며, 이 중 수상태양광 발전시설로부터 발생되는 유해물질 용출 가능성, 호소의 수면 환경변화에 따른 수질 및 수생태계에 미치는 영향 및 교란을 중점적으로 고려해야 한다. ${ }^{1,11,16,47-50)}$ 특히 수상태양광 발전시 설의 주요 기자재인 부력제, 수중케이블, 구조체 등에서 용 출 가능성이 있는 유해물질의 직접적인 영향과 수상태양광 수면 점유면적에 따른 광량 유입감소로 수온, $\mathrm{pH}, \mathrm{DO}$, 유기 물 및 영양염류 등의 수질변화, 그리고 이에 따른 수생생물 과 수생태계에 미치는 간접적인 영향에 대한 고찰이 필요하 다. ${ }^{1,1,47-50)}$ 본 연구에서는 수상태양광 발전시설 설치 시 주요 쟁점을 (1) 기자재로부터의 유해물질 용출, (2) 정체구역 발생 에 따른 수질변화, (3) 수면 점유면적에 따른 수질변화 및 수 생생물 군집변화, (4) 점유면적에 따른 수온·조도변화, (5) 전 자파로 인한 수생태계 교란으로 구분하여 Table3에 선행연구 결과를 요약 제시하였다.

한국농어촌공사(2018)는 오태저수지와 지평저수지를 대상 으로 수상태양광 발전시설의 영향권과 비영향권, 상판저수지 를 대조구로 퇴적토 내 중금속 용출 분석결과, $\mathrm{Cd}, \mathrm{As}, \mathrm{Hg}$, $\mathrm{CN}$ 은 검출되지 않은 것으로 조사되었으며, $\mathrm{Cu}, \mathrm{Pb}, \mathrm{Zn}, \mathrm{Cr}^{6+}$, $\mathrm{Ni}$ 은 미량 검출되었으나 저수지 간의 퇴적토 내 중금속의 농 도 차이가 통계학적으로 유의하지 않은 것으로 조사되었다 $(p>0.05) \cdot{ }^{19)}$ 또한 수상태양광 발전시설의 영향권과 비영향권 퇴적토 내 중금속 농도 차이도 통계학적 유의성을 나타내지 않아 수상태양광에 의한 중금속 용출 가능성은 매우 낮은 것 으로 판단하였다. ${ }^{19)}$ 노태호, 이후승(2019)은 합천호를 대상으 로 수상태양광 발전시설 영향권과 비영향권 퇴적토 내 중금속 용출 분석결과, 2011 2016년도는 미량의 중금속이 검출되었 으나 영향권과 비영향권에서 통계학적으로 유의한 차이가 나 타나지 않은 것으로 조사되었으며( $p>0.05), 2018$ 2019년도 에는 $\mathrm{Cd}, \mathrm{Hg}$ 항목이 검출되지 않은 반면, 일부 검출된 항목 (TOC, T-N, T-P, $\mathrm{Cr}, \mathrm{Cu}, \mathrm{Pb}, \mathrm{As}, \mathrm{Zn}$ )은 하천·호소 퇴적물 오염 평가 기준으로 저서생물에 유의하지 않는 기준으로 조사되 었다. ${ }^{47-50)}$ 또한, 합천호에 설치된 수상태양광 발전시설의 기 자재 시편을 직접 용출한 실험결과, 대부분의 항목이 검출되 지 않았으며, 일부 항목은 수도용 자재와 제품의 위생안전 기준 이하로 나타난 것으로 조사되었다. ${ }^{11,47-50)}$ 하지만 이러 한 조사결과는 단기간 용출 실험 결과로 장기간 지속적인 용출 실험 및 극한 조건을 반영한 다양한 실험이 필요할 것으 로 판단된다.

이인주 등(2017)은 금광저수지를 대상으로 회전식 수상태 양광 발전시설 수면 점유면적 영향권과 비영향권의 수질변 화를 분석한 결과, 수온, $\mathrm{pH}, \mathrm{DO}, \mathrm{COD}, \mathrm{T}-\mathrm{N}, \mathrm{T}-\mathrm{P}, \mathrm{Chl}-a$ 항목 은 통계학적으로 유의한 차이가 없는 것으로 조사되었다 $(p>0.05) .{ }^{16)}$ 한국농어촌공사(2018)는 오태저수지와 지평저수 지를 대상으로 수상태양광 발전시설의 영향권과 비영향권, 상 판저수지를 대조구로 수질변화를 분석한 결과, 일반항목(수 온, $\mathrm{pH}, \mathrm{DO}, \mathrm{SS}, \mathrm{EC}, \mathrm{Chl}-a)$ 과 유기물 및 영양염류(COD, TOC, T-N, T-P)의 평균값 비교에서 EC, T-N, T-P를 제외한 모든 항목에서 통계학적으로 유의한 차이가 없었으며 $(p>0.05)$, $\mathrm{EC}, \mathrm{T}-\mathrm{N}, \mathrm{T}-\mathrm{P}$ 의 호소별 차이는 대조구와 실험구 저수지의 환 경특성 차이에 기인한 것이며, 수상태양광 발전시설의 영향이 아닌 것으로 조사되었다. ${ }^{19)}$ 노태호, 이후승(2019)은 2011 2016, 2018 2019 기간 동안 합천호를 대상으로 수상태양광 발전 시설의 영향권과 비영향권의 수질변화를 분석한 결과, 대장 균군을 제외한 생활환경기준 10 개 항목 및 수온은 유의한 차 이가 없는 것으로 조사되었으며 $(p>0.05)$, 대장균군은 2013 년 추계에 일시적으로 고밀도가 나타난 것으로 조사되었 다. ${ }^{11,47-50)}$ 김학준 등(2019)은 충주댐을 대상으로 수상태양광 설치 전·후 호소의 이화학적 수질변화를 분석결과, $\mathrm{DO}, \mathrm{BOD}$, $\mathrm{TOC}, \mathrm{Chl}-a, \mathrm{EC}$ 가 통계학적으로 유의한 것으로 나타났으나 $(p<0.05)$, 이러한 결과는 비교 기간 동안 수상태양광 설치 전 강수량 대비 설치 후 강수량이 약 $40 \%$ 증가하여 영양염류 유입 증가로 인한 결과로 보고되었다. ${ }^{17)}$ 수상태양광 발전시설 설치에 따른 정체구역 발생에 따른 수질변화 관련 기존 문헌 조사결과, 수상태양광 발전시설 수면 점유면적 영향권 내 정 체구역 발생에 따른 수질변화는 통계학적으로 유의한 차이가 없으며, 유의한 차이를 보이는 문헌의 경우 조사수역의 환경 특성 차이 또는 강우사상과 같은 외부 요인이 주요 요인인 것으로 조사되었다. ${ }^{11,16,17,19)}$ 그러나, 수상태양광을 수면위에 설치 시 수상태양광의 수면 점유면적, 배열 및 종류에 따라 지속적인 수질 모니터링을 통해 수상태양광 발전시설 설치에 따른 수류순환 저해를 최소화하여 정체구역 발생을 억제하는 대책이 필요한 것으로 판단된다.

Hair와 Bell (1992)은 호주의 한 호수에서 강화 폰튠과 일 반 폰튠을 설치하여 어류의 종다양성과 종풍부성을 비교 분 석한 결과, 폰튠의 종류와 상관없이 어류는 폰튠 구조물을 은신처로 사용하는 것으로 조사되었다. ${ }^{51)}$ 한국농어촌공사 (2018)는 오태저수지와 지평저수지를 대상으로 수상태양광 발전시설의 영향권과 비영향권, 상판저수지를 대조구로 수 생생물 군집변화를 분석한 결과, 종풍부도와 종다양성은 통 계학적으로 유의한 차이를 나타내지 않았으며 $(p>0.05)$, 종 풍부도와 종다양성은 수상태양광으로부터 열린 수역에 근접 할수록 낮아지다가 수변부에 다다를수록 높아지는 일반적인 경향을 나타내었다. ${ }^{19)}$ 노태호, 이후승(2019)은 합천호를 대 상으로 수상태양광 발전시설의 영향권과 비영향권 수생생물 군집변화 분석결과, 플랑크톤류 군집지수는 안정적이며 비 영향권과 차이를 나타내지 않는 것으로 조사되었고, 어류는 수상태양광 발전시설 하부에서 치어 및 치어 포식 어종들까 지 비교적 다양한 어종이 서식하는 집어효과로 법정보호종 
Table 3. Major environmental issues of floating photovoltaic power plants.

\begin{tabular}{clll} 
Environmental issues & \multicolumn{2}{c}{ Major Findings } & Reference \\
Leaching of hazardous & - No leaching of $\mathrm{Cd}, \mathrm{As}, \mathrm{Hg}, \mathrm{CN}$ in sediments of Otae and Jipyung reservoir & KRCC (2018) \\
substances & - No detection of $\mathrm{Cu}, \mathrm{Pb}, \mathrm{Zn}, \mathrm{Cr}{ }^{6+}, \mathrm{Ni}$ in water of Otae and Jipyung reservoir & Ro and Lee \\
\cline { 2 - 4 } & $\begin{array}{l}\text { - No leaching of hazardous substances from module, frame, buoyant body, and underwater } \\
\text { cable of floating photovoltagic power plants }\end{array}$ & (2019)
\end{tabular}

- No statistical significance $(p>0.05)$ was found in differences of water temp., $\mathrm{pH}, \mathrm{DO}, \mathrm{COD}$, T-N, T-P, Chl-a, BGA between light penetration zone and light blocking zone of Geumgwang reservoir

Lee et al.

(2017)

- No statistical significance $(p>0.05)$ was found in differences of $\mathrm{pH}, \mathrm{EC}, \mathrm{DO}, \mathrm{SS}, \mathrm{Chl}-\mathrm{a}, \mathrm{COD}$, T-N, T-P between light penetration zone and light blocking zone of Otae and Jipyung reservoir

- No statistical significance $(p>0.05)$ was found in differences of pH, EC, DO, SS, Chl-a, COD,

T-N, T-P before and after installation of floating photovoltagic power plants of Otae and KRCC (2018)

Deterioration of water quality in stagnant water zone Jipyung reservoir

- No statistical significance $(p>0.05)$ was found in differences of water temp., $\mathrm{PH}, \mathrm{EC}, \mathrm{DO}, \mathrm{SS}$, Chl-a, COD, T-N, T-P between light penetration zone and light blocking zone of Hapcheon dam

Ro and Lee

- No statistical significance $(p>0.05)$ was found in differences of $\mathrm{pH}, \mathrm{COD}, \mathrm{TOC}, \mathrm{SS}, \mathrm{DO}, \mathrm{T}-\mathrm{N}$, $\mathrm{T}-\mathrm{P}, \mathrm{Chl}-\mathrm{a}, \mathrm{BOD}$, water temp., EC, and turbidity between power plant center and nearby control sites of Chungju Dam

- Positive impact on aquatic life including fish and benthic invertebrates were observed for both reinforced and general pontoons

Hair and Bell

- Providing shelters for diverse fish from feeding birds

- Negligible effect of water surface coverage on primary production of aquatic ecosystem for Karpouzoglou well-mixed water body

- Mitigation of green tide in Rapel reservoir (central Chile) with greater than $40 \%$ of water Haas et al. surface coverage ratio using ELCOM-CAEDYM model

Deterioration of water quality - No statistical significance $(p>0.05)$ was found in differences of species richness and diversity and aquatic ecosystem due to between light penetration zone and light blocking zone of Otae and Jipyung reservoir the water surface coverage

- No statistical significance $(p>0.05)$ was found in differences of species richness and diversity before and after installation of floating photovoltagic power plants of Otae and Jipyung reservoir

- No statistical significance $(p>0.05)$ was found in differences of species diversity and phytoplankton communities between light penetration zone and light blocking zone of Hapcheon dam

- Relatively diverse fish species including juvenile fish, predators, and endangered species was observed under the structure of FPVs of Hapcheon dam

- No statistical significance $(p>0.05)$ was found in differences of water temp. between light penetration zone and light blocking zone of Otae and Jipyung reservoir

- Greater sunlight irradiation of light penetration zone than light blocking zone of Otae and Jipyung reservoir

Changes in water temp. and sunlight irradiation due to the water surface coverage
Deterioration of aquatic ecosystem due to the electromagnetic waves
Sunlight irradiation of light blocking zone of Otae and Jipyung reservoir was a complex function of solar cycle, monitoring period, distance between solar panels, etc.

- No statistical significance ( $p>0.05)$ was found in differences of water temp. between power plant center and nearby control sites of Cheongpung Lake

- Lower sunlight irradiation of power plant center than nearby control sites of Chungju Dam

- No harmful responses to the magnetic and induced electrical fields among fathead minnows, sunfish, and striped bass is observed

- Low-intensity induced electric field did not appear to elicit an avoidance response of fish

Kim et al. (2019)

Cada et al. (2012)

- Highest magnetic field value of $17.330 \mu$ T observed in the transformer inside the inverter is within $20 \%$ of WHO standard value

- Magnetic field strength of $0.223 \mu \mathrm{T}$ from solar modules is extremely weak within $0.27 \%$ of Kang (2012) recommended WHO standard

- Electromagnetic field generated from the inverter of FPVs is $1 \%$ of electromagnetic field of household appliances 
의 서식도 수상태양광 구조물 주변에서 확인되었다. ${ }^{11,47-50)}$ Thodoris 등(2019)은 연안에서의 수상태양광 발전시설에 의한 잠재적 영향을 water column physical-biogeochemical model 을 사용하여 분석한 결과, 정체되어 혼합되지 않는 수체는 수 면 점유면적이 1 차 생산에 지배적인 영향을 미치나, 혼합이 이루어지는 수체는 수면 점유면적의 일부 영향을 상쇄하는 것으로 보고하였다. ${ }^{52)}$ Haas 등(2020)은 Rapel 저수지를 대상으 로 수상태양광 점유에 따른 영향을 Estuary, lake and Coastal Ocean Model-Computational Aquatic Ecosystem Dynamics (ELCOM-CAEDYM) Model을 사용하여 분석한 결과, 수체 만수면적의 $40 \sim 60 \%$ 를 점유할 경우 광량의 유입이 감소하 여 조류성장을 억제하여 녹조발생을 예방할 수 있는 것으로 보고하였다. ${ }^{53)}$ 수상태양광 발전시설 설치에 의한 수생생물 군집변화와 관련된 기존 문헌 조사 결과, 수상태양광 설치 로 인한 녹조 저감 가능성과 집어효과를 확인할 수 있었으 나 $^{11,47-53)}$, 수상태양광의 영향권 내 수생생물의 종 다양성과 종 풍부도를 확보하기 위해 지속적인 군집변화 모니터링 및 정체수역 저감을 위한 혼합시설, 치어보호 시설 등이 필요 한 것으로 판단된다.

한국농어촌공사(2018)는 오태저수지와 지평저수지를 대상 으로 수상태양광 수면 점유면적 영향권과 비영향권의 수온 과 조도를 조사한 결과, 수온은 영향권이 비영향권에 비해 $0.1 \sim 0.2^{\circ} \mathrm{C}$ 낮은 것으로 조사되었으나 통계학적으로 유의하 지 않은 것으로 분석되었으며 $(p>0.05)$, 조도는 영향권이 비 영향권에 비해 낮은 것으로 조사되었으나, 조사시기별, 태양 주기 및 수상태양광 패널 간의 상대적인 위치의 영향을 크게 받는 것으로 판단된다고 보고하였다. ${ }^{19)}$ 김학준 등(2019)은 충주댐을 대상으로 수상태양광 중앙 직하부와 약 $1 \mathrm{~km}$ 이격 한 지점의 수온과 조도를 조사한 결과, 두지점 사이의 수온 과 조도는 유사하다고 보고하였다. ${ }^{17)}$ 수상태양광 설치에 의 한 수면 점유면적의 수온과 조도 변화 관련 기존 문헌 조사 결과, 수면 점유면적에 의한 수온·조도 변화는 통계학적으 로 유의한 차이가 확인되지 않으나 $(p>0.05)^{17,19)}$, 수면 점유 면적의 영향권과 비영향권 사이에 수온과 조도의 차이는 수상 태양광 발전시설 유형 및 수면 점유율에 복잡한 함수로 판단 되어 지속적인 수온과 조도 모니터링이 필요한 것으로 판단 된다.

Cada 등(2012)은 자기장이 담수 어종에 미치는 영향을 실험 실 규모로 실험한 결과, electromagnetic fields (EMF) 민감도 가 높은 어종인 paddle fishes의 거동에는 영향을 미치지 않는 것으로 나타났으며, Sturgeon의 경우 일시적으로 행동반경을 변경하였지만, 장기적으로 관찰하였을 때 폐사율에 치명적인 영향은 나타나지 않는 것으로 조사되었다. ${ }^{54)}$ 강종식(2012)은 태양광 발전소에서 전자파를 측정한 결과, 태양광 모듈에서 최대 $0.223 \mu \mathrm{T}$ 로 측정되어 $\mathrm{WHO}$ 인체 노출 권고기준 $833 \mathrm{mG}$ 의 $0.27 \%$ 이내로 극히 미약하다고 보고하였다. ${ }^{55)}$ 한국에너지
공단(2018)은 태양광 발전소의 전자파는 전력변환장치인 인 버터 주변에서 소량 발생하며, 전자파 세기는 정부 안전기준 의 $1 \%$ 정도로 생활가전기기의 전자파 세기보다 낮은 수준인 것으로 보고하였다. ${ }^{56)}$ 수상태양광 발전시설 설치에 따라 발생 되는 전자파가 수생생물 교란 가능성과 관련된 기존 문헌 조 사 결과, 일부 어종에는 자기장에 대한 실험은 영향을 미치지 않는 것으로 확인되었으며, 태양광 발전소에서 발생되는 전자 파는 생활가전기기의 전자파보다 낮은 수준으로 보고되었다. 하지만 이러한 조사결과는 단기간 모니터링과 일부 어종의 실험결과로 수상태양광 영향권 내에서 장기간 지속적인 모니 터링 및 다양한 수생생물에 대한 위해성 평가가 필요한 것으 로 판단된다.

\section{5. 결 론}

본 고에서는 최근 기후위기로 인해 주목받는 다양한 신·재 생에너지 중 수상태양광 발전시설의 유형과 특징, 국내외 설 치사례를 조사·분석하여, 수상태양광 발전시설의 발전용량과 수면 점유율, 수질 및 수생태계에 미치는 영향에 관한 주요 환경 쟁점에 대해 고찰하였다.

1) 수상태양광 발전시설은 일반적으로 폰튠형, 프레임형, 태 양 추적형의 3 가지 유형으로 구분되어있으며, 수면 위 설치 환경을 고려한 최적의 유형을 선정하여 국가별·지역별로 다 양하게 설치되었다. 또한, 수면위에 설치되므로 구조적 안정 성 유지, 태양광 발전 효율 증대와 더불어 수환경에 미치는 영향을 최소화한 지속가능한 수상태양광 발전시설이 개발되 고 있다.

2) 국내외 수상태양광 발전시설 설치사례 조사결과, 국내의 경우 한국수자원공사, 한국농어촌공사 등 수면관리자 이외에 도 수면활용 임대 사업을 통해 민간에서도 수상태양광 발전시 설을 다양한 발전용량과 수면 점유율로 설치·운영하고 있다. 국외의 경우 미국, 유럽, 중국, 일본, 동남아시아를 중심으로 조사한 결과, 농업용, 산업용, 식수용, 빗물 저류용 및 기타(채 석장 내 인공호수, 수처리 저수지 등) 수원에 다양한 발전용량 과 수면 점유율로 설치·운영되고 있다.

3) 국내외 수상태양광 발전용량 비교결과, 2018년 하반기 기준 전 세계적으로 수상태양광 발전용량은 $1.3 \mathrm{GWp}$ 로 중국 (960 MWp), 일본(210 MWp), 한국(79 MWp), 대만(26 MWp), 영국(13 MWp) 순서로 수상태양광 발전시설이 설치되었으며, 한국을 제외한 타 국가들은 수상태양광 발전시설 유형 중 폰 튠형이 높은 발전용량을 나타내었으나, 한국의 경우 폰튠형보 다 프레임형이 높은 발전용량으로 조사되었으며, 이는 수면적 이 비교적 협소한 한국의 저수지 특성을 고려해 구조적 안정 보다는 발전효율에 가중치를 둔 결과로 판단된다. 이 외 기타 유형은 대부분 태양 추적형으로 분류되었다.

4) 국내외 수상태양광 발전시설 수면 점유율 비교결과, 중국 
과 일본의 수면 점유율이 평균 $30 \%$ 이상으로 높으며, 동남아 시아와 유럽의 수면 점유율은 평균 $15 \sim 20 \%$ 인 반면, 한국의 수면 점유율은 $10 \%$ 이하인 것으로 분석되었다. 대부분의 수 상태양광 발전시설은 농업용 수자원에 다양한 발전용량과 수 면 점유율로 설치되었으며, 농업용 이외에도 산업용, 빗물저 장, 기타 수자원에 비교적 높은 발전용량과 수면 점유율로 설 치되었다. 반면, 식수용 수자원은 다른 수자원 대비 비교적 낮은 발전용량과 수면 점유율로 수질과 수생태계에 미치는 장기적 영향과 잠재적 위해성을 고려하여 설치된 것으로 판단 된다.

5) 기자재의 유해물질 용출관련 기존 문헌 고찰결과, 퇴적 토 내 중금속 용출 분석 및 기자재 용출 실험을 통해 수상태 양광 발전시설이 수질과 수생태계에 미치는 영향이 미미한 것으로 보고되었으나, 장기간 지속적인 용출 실험 및 극한 조건을 반영한 추가 실험과 수상태양광 발전시설을 운영 시 주기적인 수환경(수질·수생태계) 모니터링이 필요한 것으로 판단된다.

6) 정체구역 발생에 따른 수질변화 관련 기존 문헌 고찰결 과, 수상태양광 발전시설 영향권 내 수질변화는 통계학적으로 유의한 차이를 보이지 않으며 $(p>0.05)$, 유의한 차이를 보인 사례의 경우 조사수역의 환경특성, 외부요인(강우사상, 수체 규모 등)이 주요 요인으로 조사되었으나, 수상태양광의 수면 점유면적, 배열 및 유형에 따라 지속적인 수질 모니터링과 더 불어 수류순환 저해 최소화 및 정체구역 발생 억제 대책이 추가적으로 필요한 것으로 판단된다.

7) 수면 점유면적에 따른 수질변화 및 수생생물 군집변화 관련 기존 문헌 고찰결과, 수상태양광 발전시설 설치로 인 한 녹조저감 가능성과 집어효과를 확인할 수 있었으나, 수 상태양광 영향권 내 수생생물의 종 다양성과 종 풍부도의 확보를 위해 물질순환을 촉진하는 혼합시설, 수생태계의 건 강성을 위한 치어보호시설 등의 설치가 필요한 것으로 판단 된다.

8) 수면 점유면적에 따른 수온·조도 변화관련 기존 문헌 고 찰결과, 수면 점유면적에 의한 수온·조도 변화는 통계학적으 로 유의한 차이가 확인되지 않았으나 $(p>0.05)$, 수면 점유면 적의 영향권과 비영향권 사이의 수온·조도의 차이는 수상태 양광 발전시설의 유형과 수면 점유율 및 외부요인(강우사상, 수체규모 등)의 복잡한 함수로 판단된다.

9) 전자파로 인한 수생태계 교란 가능성에 대한 기존 문헌 고찰결과, 대부분의 어종에는 자기장의 영향이 미치지 않는 것으로 확인되었으며, 육상태양광 발전소에서 발생되는 전자파는 생활가전기기의 전자파보다 낮은 수준으로 보고 되었으나, 수상태양광 영향권 내 장기간 지속적인 수생태계 모니터링과 수생태계 건강성 평가가 필요한 것으로 판단 된다.

\section{References}

1. J. C. Joo, N. J. Heo, S. H. Choi, S. H. Lee, Current status and major environmental issues of installation of floating photovoltaic power plants, J. Korea Water Resources Assoc., 51(11), 34-41(2018).

2. S. E. Jeong, J. W. Jeong, H. S. Kim, Y. H. Bae, Problems and directions of domestic floating photovoltaic power plants, J. Korea Water Resources Assoc., 52(3), 17-22(2019).

3. C. S. Won, Technical trend of floating PV system, The Korean Solar Energy Society, J. Korean Solar Energy Soc., 13(1), 18-23(2015).

4. Ministry of Trade Industry and Energy, Renewable Energy 3020 Implementation Proposal, Ministry of Trade Industry and Energy, Sejong, Korea(2017).

5. J. Y. Park, Y. J. Lee, D. J. Chun, M. J. Lee, Estimation of environmental and social potential of floating photovoltaic power plants in agricultural reservoirs, Korea Environment Institute, KEI Pocus, 6(4), 1-24(2018).

6. P. Ranjbaran, H. Yousefi, G. B. Gharehpetian, F. R. Astaraei, A review on floating photovoltaic (FPV) power generation units, Renew, Sustain. Energy Rev., 110, 332-347 (2019).

7. Y. K. Choi, A study on power generation analysis of floating PV system considering environmental impact, Int. J. Software Eng. App., 8(1), 75-84(2014).

8. G. H. Yeo, Technology trend in floating photovoltaic power plants, Konetic Report, Seoul, Korea(2016).

9. Ministry of Environment, A study on systematic management of dam water surface and establishment of utilization plan, Ministry of Environment, Sejong, Korea(2019).

10. S. Y. Kim, A study on the efficiency analysis of rotary type floating photovoltaic power plants, Hanyang university, Seoul, Korea(2015).

11. T. H. Ro, W. S. Lee, Truth and false of the environmental issues of the floating photovoltaic power plants-fact check, KEI Pocus, 7(9), 1-18(2019).

12. World Bank Group, Where sun meets water: floating solar market report, World Bank, Washington, D.C., USA(2019).

13. M. Acharya, S. Devraj, Floating Solar Photovoltaic (FSPV): A Third Pillar to Solar PV Sector?, The Energy and Resources Institute, New Delhi, India(2019).

14. I. A. Shiklomanov, World freshwater resources. Water in crisis: a guide to the world's fresh water resources, Oxford University Press, New York(1993).

15. Korea Rural Community Corporation, Studies on water pollution and the management of water quality of the agricultural reservoirs with the purpose of multiple utilization( I ), Korea Rural Community Corporation, Naju, Korea(2004).

16. I. J. Lee, J. C. Joo, C. S. Lee, G. Y. Kim, D. Y. Woo, J. H. Kim, Evaluation of the water quality changes in agricultural reservoir covered with floating photovoltaic solar-tracking systems, J. Korean Soc. Environ. Eng., 39(5), 255-264(2017). 
17. H. J. Kim, S. N. Kwak, M. Yoon, I. K. Kim, Y. S. Kim, D. S. Kim, Effect of a floating photovoltaic system (FPV) at Chungju dam (Cheongpung lake) on water quality, J. Ecol. Environ., 52(4), 293-305(2019).

18. Korea Rural Community Corporation, Ecological effects of water use in agricultural reservoir: fishing and floating photovoltaic power plant( I ), Korea Rural Community Corporation, Naju, Korea (2017).

19. Korea Rural Community Corporation, Ecological effects of water use in agricultural reservoir: fishing and floating photovoltaic power plant( $\amalg)$ Korea Rural Community Corporation, Naju, Korea (2018).

20. I. H. Joo, Overview and status of floating photovoltaic power generation technology, J. Electr. World, 3, 37-41(2014).

21. H. J. Joo, N. H. Lee, S. W. Lee, Floating Photovoltaic Power Generation System, J. Korean Soc. Adv. Comp. Struc., 4(4), 31-39(2013).

22. Z. Dobrotkova, Where sun meets water: floating solar handbook for practitioners, World Bank Group, Washington, D.C., USA(2019).

23. Y. K. Choi, Y. G. Lee, A study on development of rotary structure for tracking-type floating photovoltaic system. Int.

J. Precis. Eng. Manuf., 15(11), 2453-2460(2014).

24. A. G. Lee, G. W. Shin, S. T. Hong, Y. K. Choi, A study on development of ICT convergence technology for tracking-type floating photovoltaic systems, Int. J. Samrt Grid Clean Energy, 3(1), 80-87(2014).

25. K-water Home page, https://www.kwater.or.kr, April(2021).

26. Korea Hydro \& Nuclear Power, https://www.khnp.co.kr, April(2021).

27. Korea East-West Power, https://ewp.co.kr, April(2021).

28. Ciel \& Terre, https://www.ciel-et-terre.net, April(2021).

29. D3Energy, https://d3energy.com, April(2021).

30. Techwin, http://www.techwin.co.kr, April(2021).

31. SUNGROW, https://en.sungrowpower.com, April(2021).

32. Tokyo Century Corporation, https://www.tokyocentury.co.jp, April(2021).

33. A. Sahu, N. Yadav, K. Sudhakar, Floating photovoltaic power plant: a review, J. Renew. Sustai. Energy Rev., 66, 815-824 (2016).

34. Jintech New Energy, https://www.jntechenergy.com, April (2021).

35. Xiamen Mibet New Energy, https://www.mbt-energy.com, April(2021).

36. Kyoraku Co., http://www.krk.co.jp, April(2021).

37. Takiron Engineering, https://www.takiron-ci.co.jp, April(2021).

38. Sumitomo Mitsui Construction, https://www.smcon.co.jp, April(2021).

39. West Energy Solutions, https://www.west-gr.co.jp, April(2021).

40. Ibiden Engineering, https://www.ibiden.com, April(2021).

41. Korea Hydro \& Nuclear Power, Saemangeum floating photovoltaic plants project, environmental impact assessment (draft) assessment summary, Korea Hydro \& Nuclear Power, Gyeongju, Korea(2019).

42. Scotra Co., http://scotra.co.kr, April(2021).

43. LG-CNS, https://www.lgcns.co.kr/, April(2021).

44. Seafelx, http://www.seaflex.net, April(2021).

45. LS Industrial System Co., https://www.lselectric.co.kr, April(2021).

46. Korea Institute of Civil Engineering and Building Technology, Preliminary study on development of buoyant body and mooring system for marine solar power plant, 2018.

47. K-water, Research on environmental impact analysis and system improvement plan of floating solar power plants business, Korea Environmental Institute (2012).

48. K-water, Environmental monitoring and environmental safety verification for floating solar power plants business, Korea Environmental Institute, Sejong, Korea(2014).

49. K-water, Floating photovoltaic system Environment Council Operation and Environmental Monitoring, Korea Environmental Institute, Sejong, Korea(2016).

50. K-water, Environmental safety evaluation according to the installation of floating photovoltaic systems, Korea Environmental Institute, Sejong, Korea(2019).

51. C. A. Hair, J. D. Bell, Effects of enhancing pontoons on abundance of fish: initial experiments in estuaries, Bull. Mar. Sci., 51(1), 30-36(1992).

52. T. Karpouzoglou, B. Vlaswinkel, J. V. D. Molen, Effects of large-scale floating (solar photovoltaic) platforms on hydrodynamics and primary production in a coastal sea from a water column model, Ocean Sci., 16(1), 195-208(2020).

53. J. Haas, J. Khalighi, A. de la Fuente, S. U. Gerbersdorf, W. Nowak, P. J. Chen, Floating photovoltaic plants: ecological impacts versus hydropower operation flexibility, Energy Convers. Manag., 206, 112414-112422(2020).

54. G. F. Cada, M. S. Bevelhimer, A. M. Fortner, K. P. Riemer, P. E. Schweizer, Laboratory studies of the effects of static and variable magnetic fields on freshwater fish, Oak Ridge National Laboratory, Oak Ridge, USA pp. 1-42(2012).

55. J. S. Kang, Solar power plant electromagnetic environment survey research, JKIEES, 23(1), 21-36(2012).

56. Korea New and Renewable Energy Center, Facts regarding solar \& wind power, Korea New and Renewable Energy Center, Ulsan, Korea(2018).

\section{Declaration of Competing Interest}

The authors declare that they have no known competing financial interests or personal relationships that could have appeared to influence the work reported in this paper. 


\section{Authors and Contribution Statement}

\section{Chae Min Ahn}

Department of Environmental Engineering, Hanbat National University, MS candidate, ORCID (1) 0000-0003-1766-5474: Conceptualization, Methodology, Validation, Writing - original draft, Writing-review and editing.

\section{Jin Chul Joo}

Department of Civil \& Environmental Engineering, Hanbat National University, Professor, ORCID(D) 0000-0001-8551-3945: Conceptualization, Validation, Writing-original draft, Writing review and editing.

\section{Jin Ho Kim}

Land \& Housing Institute, MS, ORCID (1) 0000-0003-1505-723X: Methodology, Validation.

\section{Sun Hwa Choi}

Korea Association for Aquatic Ecosystem Restoration, Ph.D, ORCID(D) 00000-0002-2516-5720: Funding acquisition, Supervision.

\section{Jin Seon Jang}

Department of Civil \& Environmental Engineering, Hanbat National University, MS candidate, ORCID (C) 0000-0002-11896725: Methodology, Validation.

\section{Hyeon Woo Go}

Department of Civil \& Environmental Engineering, Hanbat National University, MS candidate, ORCID (1) 0000-0002-9384-1954: Methodology, Validation. 